\title{
TINJAUAN FIQH MUAMALAH PADA PRAKTIK SEWA JASA LAUNDRY SYARIAH ARRANSHA
}

\author{
Dewi Indrayani \\ Fakultas Syariah IAIN Langsa \\ dewi.indrayani.se@gmail.com
}

\begin{abstract}
This study aims to discuss about how the practice of sharia laundry services in Arransha Langsa City? And how is the fiqh muamalah review of the practice of syari'ah laundry services in Arransha Langsa City?. This study uses qualitative methods with descriptive and empirical analysis and data collection methods by observation, interviews and documentation. The results of this study explain that the practice of Arransha sharia laundry services in Langsa City is in accordance with laundry procedures in general, but the emphasis is on the practice of Arransha sharia laundry services that have not used the overall thaharah concept. Holiness is part of faith. The condition for the validity of prayer is that the body, clothes and place of worship are clean. Based on the fiqh muamalah review of Arransha's laundry practice, it has not fulfilled the fiqh muamalah elements such as a violation of the contract stated in the bill of lading, namely compensation for goods by 50\%, but in reality this is not the case. The Arransha sharia laundry party did not fulfill it as agreed. The advice that researchers can give is that the Arransha sharia laundry party should provide compensation (Dhaman) for damaged or lost consumer goods as agreed in the contract.
\end{abstract}

\section{Keywords: Rent, Syari'ah Laundry and Fiqh Muamalah}

\begin{abstract}
Abstrak
Penelitian ini bertujuan untuk membahas tentang Bagaimana praktik jasa laundry syari'ah Arransha Kota Langsa? Dan Bagaimana tinjauan fiqh muamalah terhadap praktik jasa laundry syari'ah Arransha Kota Langsa?. Penelitian ini menguunakan metode kualitatif dengan analisis deskriptif dan empiris dan metode pengumpulan data dengan observasi, wawancara dan dokumentasi. Adapun hasil penelitian ini menjelaskan bahwa praktik jasa laundry syari'ah Arransha Kota Langsa sudah sesuai dengan prosedur laundry pada umumnya, namun Penekannya di praktik jasa laundry syariah Arransha ini belum menggunakan konsepsi thaharah secara keseluruhan. Kesucian sebagian dari iman. Syarat sah tidaknya sholat adalah suci bersih badan, pakaian dan tempat ibadah. Berdasarkan tinjauan fiqh muamalah terhadap praktik laundry Arransha, belum memenuhi unsur fiqh muamalah seperti adanya pelanggaran akad yang tertera dalam nota bon, yaitu ganti rugi barang sebesar 50\%, namun kenyataannya tidak demikian. Pihak laundry syariah Arransha tidak menunaikan sebagaimana yang telah diakadkan. Saran yang dapat peneliti berikan yaitu Seharusnya pihak laundry syariah Arransha
\end{abstract}


memberikan ganti rugi (Dhaman) barang konsumen yang rusak maupun hilang sebagaimana yang telah disepakati dalam akad.

\section{Kata Kunci: Sewa, Laundry Syari'ah dan Fiqh Muamalah}

\section{Pendahuluan}

Seiring perkembangan zaman, materi muamalah cenderung makin bertambah oleh pakar hukum Islam. Hal ini menjelaskan materi pengetahuan muamalah termasuk bagian penting dari studi Islam yang harus diperjuangkan karena tidak semua umat Islam mengerti akan pelaksanaan kegiatan muamalah sesuai dengan prinsip-prinsip Alquran (Shihab, 2017).

Literatur upah menjadi dasar terbentuk usaha-usaha jasa seperti usaha jasa laundry. Keharusan pemberi jasa adalah memenuhi semua kewajiban yang termanifestasi dalam perjanjian atau nota bon faktur dan si pemberi jasa benar-benar harus bersungguh-sungguh mengerahkan kemampuannya sesuai dengan syarat-syarat yang tertera dalam kontrak secara professional (Sudiarti, 2018).

Penyempurnaan rangkaian sewa menyewa atau akad maka harus ada bentuk perjanjian sebagai pedoman yang disepakati sebagai akad dalam kegiatan tersebut. Kaidah ini diwujudkan dalam bentuk akad antara kedua belah pihak yang melakukan akad tersebut yakni pengusaha jasa laundry syari'ah dengan pelanggan. Pengakuan ini sebagai tujuan untuk meniadakan ketidakadilan dan ketidak jujuran serta lepas tanggung jawab terhadap suatu perjanjian (Eprianti \& Adhita, 2017).

Dalam kehidupan sehari-hari, masyarakat memiliki kebutuhankebutuhan yang harus dipenuhi baik kebutuhan primer, sekunder maupun tersier. Ada kalanya masyarakat tidak memiliki cukup dana untuk memenuhi kebutuhan hidupnya (Agustinar, 2021). Usaha Jasa laundry juga termasuk usaha mikro, kecil dan menengah dapat dijadikan salah satu solusi usaha untuk memenuhi kebutuhan hidup. Masyarakat pada umumnya sering menggunakan jasa laundry karena mobilitas masyarakat industrialisasi semakin meningkat apalagi kedua suami istri bekerja. Tentu untuk mencuci pakaian semakin sulit dan jasa yang akan dipilih pasti laundry. Biasanya dalam unit usaha sudah ditentukan harganya serta waktu pengambilan cucian oleh pihak penyedia jasa. Sebagai pemegang akad atau akta bon, seharusnya pihak laundry memberi tahu pelanggan pada saat pelanggan menyerahkan pakaiannya atau pada saat terjadinya akad sehingga adanya kejelasan dalam akad tersebut (Pristi, 2020).

Konteks sekarang bermunculan kegiatan jasa laundry berbasis syari'ah memiliki perbedaan dengan usaha jasa laundry pada umumnya seperti laundry kiloan yang konvensional.(HAK \& Yuswalina, 2019) Perbedaan kedua laundry tersebut terletak pada proses pencucian dan akad perjanjian serta penentuan harga. Laundry berbasis syari'ah menggunakan pencucian dengan proses thaharah dan harga yang ditawarkan lebih terjangkau sesuai kualitas yang ditawarkan bersih dan suci serta akad tidak menyimpang. Proses pencucian 
dengan thaharah adalah proses pencucian yang tidak hanya memberikan bersih, wangi dan rapi saja akan tetapi memiliki nilai kesucian pada pakaian sehingga dapat digunakan untuk beribadah, sedangkan laundry kiloan tidak memiliki nilai suci dan hanya mencuci dengan mesin secara langsung, bahkan harga lebih tidak ekonomis dan nilai kesucian dipertanyakan (Veri, 2020a).

Laundry syariah Arransha yang berada di gampong Paya Bujok Seuleumak Kota Langsa. Laundry syari'ah dalam artian ingin menerapkan prinsip-prinsip syari'ah dalam praktik usahanya. Model pengambilan barang jika terjadi kecacatan barang konsumen maka penyelesaiannya dilakukan secara kekeluargaan yaitu mengganti barang konsumen berjumlah $50 \%$ dari harga barang. Akan tetapi faktanya, ketika ada pengembalian barang hal ini tidak ditunaikan. Perlu dijelaskan praktik laundry syari'ah Arransha sebenarnya tidak sesuai dengan konsep sewa menyewa dalam prinsip ekonomi Islam. Selama ada bukti dari konsumen dan layak maka barang yang hilang ataupun rusak tetap dikembalikan dan diperbaiki (Djuwaini, 2008). Selain itu juga pihak jasa laundry Arransha menghapuskan sisa paket jika paket laundry tidak habis dalam kurun waktu satu bulan dan ji

ka konsumen tidak berlangganan lagi di laundry syariah Arransha . Disini pelanggan merasa kecewa dan dirugikan oleh pihak jasa laundry syariah Arransha (Pristi, 2020).

Seharusnya motto laundry syariah yang digunakan laundry Arransha harus sesuai dengan prinsip-prinsip kaidah fiqh muamalah salah satu kaidahnya yakni menolak mafsadah lebih diutamakan daripada meraih maslahah. Pihak jasa laundry syariah tidak memenuhi ketentuan-ketentuan yang telah dituangkan dalam nota faktur yaitu ganti rugi $50 \%$ dari harga barang. Dalam hal ini pihak jasa laundry telah melanggar akad yang telah disepakati di awal transaksi. Ini menyebabkan kekecewaan dan kerugian konsumen terhadap jasa usaha laundry syari'ah Arransha (Nuh, 2020).

Melihat permasalahan dari hasil uraian yang dilakukan oleh peneliti tentang pelaku usaha laundry dengan konsumen laundry, maka peneliti ingin meneliti tentang Praktik Jasa Laundry Syari'ah Arransha Kota Langsa di Tinjau Menurut Fiqh Muamalah.

Berdasarkan rangkaian kontruksi diatas, merumuskan fokus kajian sebagai berikut: Bagaimana praktik jasa laundry syari'ah Arransha Kota Langsa? Dan Bagaimana tinjauan fiqh muamalah terhadap praktik jasa laundry syari'ah Arransha Kota Langsa?

\section{Metode Penelitian}

Penelitian ini menguunakan metode deskriptif yang memetakan secara holistik laundry syari'ah Arransha secara sistematis, faktual dan akurat mengenai fakta-fakta internal atau eksternal serta hubungan antar fenomena yang diselidiki bahkan study case yang terjadi terhadap pelanggan laundry syari'ah Arransha terakhir menganalisisnya sesuai dengan tinjauan fiqh muamalah yang berlaku (Nazir, 1998). 
Pendekatan penelitian dalam penelitian ini menggunakan pendekatanpendekatan yang dianggap relevan dalam penelitian empiris (Arikunto, 2013)

\section{Bagan alur penelitian sebagai berikut:}

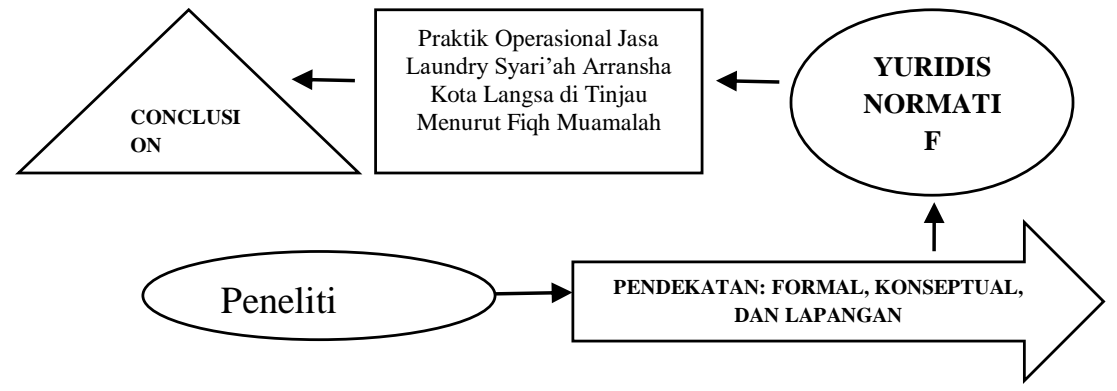

Adapun Jenis penelitian kualitatif yang digunakan peneliti dengan alasan karena dalam penelitian ini tidak menggunakan angka dalam mengumpulkan data (Ahmad, 2010). Narasumber yang digunakan adalah pemilik laundry syariah Arransha Kota Langsa, beberapa karyawan dan limaorang konsumen. Penelitianini dilakukan di Laundry Arransha Desa Paya Bujok Seuleumak Kecamatan Langsa Baro Kota Langsa. Kemudian di perpustakaan Institute Agama Islam Negeri Langsa. Adapun sumber data dapat diperoleh dari pihakpihak yang bersangkutan seperti masyarakat sebagai konsumen jasa laundry dan karyawanlaundry syariahArranshaKota Langsa (Dkk, 2006). Untuk memperoleh data yang valid, dalam penelitian penulis menggunakan beberapa metode pengumpulan data yaitu observasi, Wawancara dan dokumentasi (Sayono, 2011).

\section{Fiqh Muamalah}

Fiqh muamalah dalam penelitian ini dijadikan sebagai grand theory. Kata fiqh muamalah secara majemuk terdiri dari kata fiqh dan muamalah. Kata paham, mengetahui dan melaksanakan merupakan penjelasan dari bahasa fiqh. Kemudian kata a'lama ya'limu dan muamalah yang secara etimologi sama dengan makna saling berbuat (al-mufa'alah) perkataan ini sebenarnya berasal dari kata muamalah yang berasal dari bahasa Arab. Kata bahasa Arab tersebut menerangkan aktifitas ini menjelaskan suatu kegiatan yang dilakukan oleh seseorang dengan orang lain dalam memenuhi kebutuhan masing-masing. Kemudian ada juga yang menjelaskan bahwa hukum-hukum yang berkaitan dengan tindakan yang dilakukan oleh manusia dalam hal hartanya seperti jual beli, sewa menyewa, gadai dan lain-lain berikut adalah pengertian dari sisi terminologi fiqh muamalah (Abdullah, 2011).

Definisi di atas menjelaskan kepada individu atau seseorang yang sudah mukallaf. Artinya seorang individu yang sudah dibebani hukum, mereka itu sudah baligh dan berakal lagi cerdas.

Norma Islam, lahan muamalah sangat luas sehingga Alquran dan sunnah secara mayoritas lebih banyak membicarakan persoalan muamalah secara global. Hal ini menunjukkan bahwa Islam memberikan peluang kepada manusia untuk melakukan inovasi terhadap berbagai bentuk muamalah yang 
dibutuhkan dalam kehidupan mereka dengan syarat tidak keluar dari prinsipprinsip yang telah ditentukan (Dewi, 2005).

Kesimpulan diatas menjelaskan bahwa secara garis besar definisi atau pengertian hukum ekonomi Islam (fiqh muamalah) yaitu hukum-hukum yang berkaitan dengan tata cara berhubungan antar sesama manusia, baik hubungan tersebut bersifat kebendaan maupun dalam bentuk perjanjian perikatan (Masruroh, 2021). Hal ini menjelaskan secara utuh bahwa salah satu pembagian lapangan pembahasan hukum muamalah yang lebih menekankan ibadah, artinya lapangan pembahasan hukum fiqh mualamah adalah hubungan interpersonal antar sesama manusia, bukan hubungan vertikal manusia dengan Tuhannya, rangkaian-rangkaian ini diartikan sebagai konsepsi fiqh muamalah secara garis besar (Salahudiin, 2007).

Hukum personal, fiqh muamalah atau dapat dikatakan sebagai hukum perdata Islam hanya mencukupkan pembahasannya pada hukum perikatan tidak membahas hukum perorangan dan hukum kebendaan secara khusus tercantum dalam Kitab Undang-undang Hukum Perdata. Konteksnya sekarang fiqh muamalah dapat juga dikatakan sebagai hukum perdata Islam, hanya saja bila dibandingkan dengan fiqh muamalah klasik agak berbeda (Az-Zuhaili, 1984).

Kemudian pembahasan yang bersifat adabiyah dengan menjelaskan beberapa bentuk perikatan dan perjanjian secara rinci dan jelas lengkap dengan rukun dan syaratnya. Ada pula sistematik pembahasannya langsung yang bersifat madiyah yaitu kepada materi dan beberapa bentuk transaksi yang ada, hal ini dapat dilihat pada kitab-kitab fiqh para imam mazhab yang empat. Pembahasan terhadap bentuk-bentuk transaksi ini, para fuqaha telah membahasnya dengan sistemik yang berbeda-beda dan sangat beragam. Hal di atas bagian dari klasifikasinya tata cara pelaksanaannya yang bersifat adabiyah seperti masalah ijab qabul (Nur Khusna et al., 2021). Kemudian, tentang bentuk-bentuk transaksi yang bersifat madiyah. Seperti jual beli, sewa menyewa, wakalah, hiwalah, wadi'ah dan lain-lain (Karim, 2005).

Di antara pembahasan adalah mengenai akad dan permasalahannya, milik dan bagaimana cara mendapatkannya, harta dan permasalahannya, jual beli dengan segala bentuk dan jenisnya, syirkah, mudharabah, dan berbagai bentuk transaksi lainnya. Artinya ruang lingkup pembahasan dibidang muamalah ini telah memberikan kontribusi yang sangat berharga untuk kelangsungan hidup manusia, karena Alquran dan hadis membicarakan persoalan muamalah secara global dan dengan prinsip-prinsip secara umum demi terciptanya keadilan diantara sesama manusia. Penyusunan oleh fuqaha dalam pembahasan fiqh muamalah ini hanya pada urutan prioritas saja, namun pada prinsipnya dalam pembahasan yang berkaitan dengan materi tidak terdapat perbedaan yang siginifikan (Karim, 2005).

\section{Teori Ijarah}

Al-ijãrah yang dikemukakan ulama fiqh salah satu ulama Hanafiyah mendefinisikannya dengan: transaksi terhadap suatu manfaat dengan imbalan. 
Syafi'iyah menjelaskan ijãrah adalah akad atas suatu manfaat tertentu, bersifat mubah dan boleh dimanfaatkan dengan kompensasi atau imbalan tertentu. Malikiyah mengatakan, ijärah adalah perpindahan kepemilikan manfaat sesuatu yang dibolehkan dalam waktu tertentu dengan suatu kompensasi tertentu, semua ini adalah uraian dari terminologi ijärah (Karim, 2005). Kontruksi di atas menjelaskan bahwa akad al-ijãrah bisa juga diartikan sebagai akad pemindahan hak pakai atas barang atau jasa dalam waktu tertentu dengan suatu imbalan (upah sewa), yang tidak diikuti oleh pemindahan hak milik atas barang yang disewa. Subtansi akad ijãrah terletak pada pengambilan manfaat atas barang atau jasa yang diimbangi dengan upah dalam waktu tertentu (Priestnall et al., 2020).

Teori ujrah sebagai imbalan yang diberikan atau yang diminta atas suatu pekerjaan yang dilakukan. Dalam penelitian tesis disini digunakan sebagai middle theory karena secara literatur kata ujrah sendiri adalah upah itu sendiri. Ada juga yang menjelaskan bahwa arti upah sama dengan sewa menyewa sehingga mengenai ujrah ini termasuk dalam pembahasan ijarah yang sama dengan arti upah seperti dalam kamus bahasa Arab. Kemudian uang yang dibayarkan sebagai pembalas jasa atau sebagai pembayar tenaga yang sudah dikeluarkan untuk mengerjakan sesuatu disebut sebagai upah dalam kamus bahasa Indonesia.

Sewa jasa, atau imbalan berarti upah dalam bahasa Arab secara konsepsi lafalnya berasal dari kata ijärah, kata ujrah dan ijärah punya relevansi yang kuat. Al-ijärah merupakan salah satu bentuk kegiatan muamalah, dalam memenuhi keperluan hidup manusia, seperti sewa menyewa, kontrak, atau menjual jasa perhotelan, dan lain-lain (Harun, 2017).

Suatu akad pemindahan hak guna atas barang atau jasa melalui pembayaran upah sewa, tanpa diikuti dengan pemindahan kepemilikan atas barang itu sendiri bisa juga dipahami sebagai ijarah, dengan demikian dalam akad ijarah tidak ada perubahan kepemilikan (Priestnall et al., 2020).

Adapun rukun dari konsep ijarah, yaitu Pertama, pelaku akad, yaitu mustajir (penyewa) adalah pihak yang menyewa aset dan mu'jir/muajir (pemilik) adalah pihak pemilik yang menyewakan aset. Kedua, objek akad yaitu ma'jur (aset yang disewakan) dan ujrah (harga sewa). Ketiga, ijab dan qabul. Ketiga hal tersebut merupakan rukun dari akad ijarah yang harus dipenuhi dalam transaksi. Kemudian disamping itu ada juga syarat ijarah yang harus ada, agar terpenuhi ketentuan-ketentuan hukum Islam sebagai berikut: (Harun, 2017) a. Jasa atau manfaat yang akan diberikan oleh aset yang disewakan tersebut harus tertentu dan diketahui dengan jelas oleh kedua belah pihak; b. Kepemilikan aset tetap pada yang menyewakan yang bertanggung jawab pemeliharaannya, sehingga aset tersebut harus dapat memberi manfaat kepada penyewa; c. Akad ijarah dihentikan pada saat aset yang bersangkutan berhenti; dan d. Memberikan manfaat kepada penyewa. Jika aset tersebut rusak dalam periode kontrak, akad jjarah masih tetap berlaku.

\section{Teori Akad}


Teori memegang, perjanjian, percampuran, menyatukan, membangun atau mendirikan. Bisa juga berarti kontrak (perjanjian yang tercatat) sedangkan menurut para ahli akad berarti ikatan atau kesepakatan, kalimat tersebut berasal dari kata akada penggalan dari kata akad dan berasal dari bahasa Arab (Ma'luf, 1986).

Selanjutnya ikatan antara dua perkara baik ikatan secara nyata maupun ikatan secara maknawi dari satu segi maupun dari dua segi, hal ini makna dari etimologi akad. Kemudian, membagi akad dilihat dari dua aspek yaitu umum dan khusus menurut ulama fiqh. Akad secara umum adalah segala sesuatu yang dikerjakan oleh seseorang berdasarkan keinginanya sendiri seperti wakaf, talak, pembebasan, atau sesuatu yang pembentukannya membutuhkan keinginan dua orang hal ini merupakan uraian dari terminologi akad, seperti jual-beli, perwakilan dan gadai. Pengertian akad secara umum diatas adalah sama dengan pengertian akad dari aspek bahasa menurut pendapat ulama Syafi'iyyah, Malikiyyah, dan Hanabilah. Namun secara khusus akad dimaknai sebagai pengaitan ucapan salah seorang yang berakad dengan yang lainnya secara syara' pada aspek yang tampak dan berdampak pada objeknya. Akad juga dimaknai sebagai perikatan yang ditetapkan dengan ijab-qabul berdasarkan ketentuan syara' yang berdampak pada akad yang ditentukan (Azmi, 2014).

Dua istilah berhubungan dengan perjanjian. yaitu al'aqdu (akad) dan al'ahdu (janji). Penegasan akad secara bahasa adalah ikatan, mengikat, kata ikatan sendiri maksudnya adalah menghimpun atau mengumpulkan dua ujung tali dan mengikatkan salah satunya pada yang lainnya hingga keduanya bersambung dan menjadi seutas tali yang satu. Sedangkan istilah overeenkomst atau perjanjian yaitu suatu pernyataan dari seseorang untuk tidak atau mengerjakan sesuatu yang tidak berkaitan dengan orang lain, hal ini hampir sama dengan istilah al-'ahdu (Asutay, 2012). Hal ini tercatat dalam Alquran surah Al-Imran ayat 76 sebagai berikut:

(bukan demikian), Sebenarnya siapa yang menepati janji (yang dibuat) nya dan bertakwa, Maka Sesungguhnya Allah menyukai orang-orang yang bertakwa.

Rukun-rukun akad sudah dijelaskan sebagai berikut: Pertama, uraiannya ialah orang yang berakad ('aqid), contoh: penjual dan pembeli sekaligus orang yang melakukan akad. Keberadaannya sangat penting karena tidak akan pernah terjadi akad manakala tidak ada aqid. Kedua, sesuatu yang diakadkan (ma'qud alaih), contoh: harga atau barang. (al-Ma'qud Alaih) adalah objek akad atau benda-benda yang dijadikan akad yang bentuknya tampak dan membekas. Barang tersebut dapat berbentuk harta benda, seperti barang dagangan, benda bukan harta seperti dalam akad pernikahan, dan dapat pula berbentuk suatu kemanfaatan seperti dalam masalah upah-mengupah dan lain-lain. Ketiga, tujuan pokok dalam melakukan akad diartikan sebagai maudhu al-'aqd. Keempat, shighat al'aqd terdiri dari ijab qabul (Huda, 2011). 
Perspektif fuqaha fiqh terhadap akad dalam perkembangannya, ada tiga pendapat yang dikemukakan oleh kalangan ahli sebagai berikut: Pertama, akad harus menggunakan shighat ijab-qabul jika tidak maka akad tersebut tidak sah. Kedua, akad harus dengan perbuatan (af'al) sehingga akad jual beli tetap sah. Ketiga, Segala hal yang menunjukkan maksud dan tujuan akad, baik berupa ucapan maupun perbuatan sekaligus dengan akad bisa berbentuk

Kemudian teori akad disini juga menerangkan ketika kesepakatan bersama (aqad al-iqalah) ternyata faktanya tidak sesuai dengan perjanjian diawal maka dibolehkan melakukan fasakh akad berdasarkan klausul-klausul yang ada di bon laundry syari'ah Arransha. Perlu dijelaskan ketika pelanggan dan pihak laundry tidak sesuai dengan kesepakatan bersama maka secara teori penyelesaiannya sebagai berikut: (Al-Mas'adi, 2002)

1) Fasakh karena rusaknya akad, hal ini terjadi jika akad berlangsung berjalan fasid seperti sementara maka akad wajib dibatalkan baik oleh yang berakad atau keputusan hakim.

2) Pembatalan karena khiyar, shahibul khiyar berhak melakukan fasakh jika menghendakinya kecuali dalam kasus khiyar 'alibi (cacat). Hal ini dilakuan setelah terjadi penyerahan barang terkecuali atas kerelaan keduanya.

3) Fasakh berdasarkan adanya iqalah yaitu melakukan fasakh perjanjian (akad) berdasarkan kesepakatan kedua belah pihak. Sehingga jika salah satu pihak merasa menyesal lalu menghendaki untuk membatalkannya, yang demikian ini hanya bisa terjadi atas kesepakatan.

4) Fasakh karena tidak ada realisasi, misalnya ketika pengerjaan terjadi hal yang diinginkan itu tidak sesuai kontrak maka dibolehkan membatalkan selama realisasinya tidak tepat guna.

5) Pembatalan karena telah jatuh tempo atau karena tujuan akadnya telah terealisasi sehingga dengan sendirinya fasakh.

\section{Usaha Laundry}

Usaha laundry sebagai jasa yang kegiatannya melakukan cuci dan menyetrika pakaian. Proses usaha laundry ini awalnya hanya untuk kalangan terbatas, seperti laundry untuk para tamu yang menginap dihotel disebut sebagai usaha laundry. Perkembangannya semakin banyaknya ketersediaan mesin cuci dengan harga yang relatif terjangkau, disertai munculnya teknologi baru seperti alat pengering yang membuat pakaian tidak perlu lagi dijemur. Artinya kebiasaan mencuci manual pasti akan sulit menjadi kering oleh karenanya banyak masyarakat yang menyerahkan pakaian kotor mereka ke laundry (Ekasari Lieharyani Lokmansyah \& Rika Harini, 2019).

Bisnis laundry dengan kegiatan terdapat standar operasional prosedur untuk pencucian pakaian dibedakan menjadi dua sebagai berikut: Pertama, pencucian dengan menggunakan dasar perhitungan dari berat timbangan pakaian disebutkan sebagai pencucian kiloan. Keunggulan dari pencucian kiloan yaitu harganya yang terjangkau dan proses pencucian dapat dilakukan 
dengan cepat, pencucian kiloan terdiri dari: a. cuci komplit, b. cuci saja, c. setrika, d. keringkan, e. cuci tidak dicampur. Kedua, pencucian dengan perhitungan potongan pakaian, dengan perhatian khusus disesuaikan bahan dan jenis pakaian sesuai washing care label tips sebagai petunjuk pencucian yang tertera pada label dalam pakaian hal ini dinamakan sebagai pencucian khusus. Biasanya pakaian akan lebih awet dan terjaga warna aslinya walau telah dicuci aberkali-kali dan selalu dalam keadan rapi karena setiap satu jenis pakaian diberi hanger dan plastik sendiri (Handoko, 2013).

Pencucian kiloan bertujuan untuk mempermudah dan lebih mengefektifkan didalam proses karena perlunya pemisahan pakaian dalam pencucian pakaian diberi hanger dan plastik sendiri. Kemudian yang paling perlu adalah sistem pemisahan pakaian dalam. Kapasitas mesin untuk satu kali mencuci yaitu $5 \mathrm{~kg}$ pakaian, tentunya konsumen yang memberikan order tidak semua genap $5 \mathrm{~kg}$. Oleh karena itu agar dalam proses pencucian dapat lebih efisien, pakaian konsumen disatukan untuk mendapatkan jumlah $5 \mathrm{~kg}$. Namun pakaian yang disatukan rawan terjadi resiko tertukar antar pakaian dan terjadi kelunturan (Handoko, 2013).

Berjalannya sebuah unit usaha laundr sebagai berikut:

a. pemberian nomor dan penimbangan,

b. Pemisahan pakaian luntur, dan

c. penggabungan pakaian.

Pasca proses pencucian dilanjutkan dengan proses pengeringan. Pakaian keluar dari mesin cuci telah kering $80 \%$ untuk proses selanjutnya pakaian dikeringkan menggunakan dryer agar dapat kering 100\%. Setelah proses pengeringan dilakukan, proses setrika pakaian merupakan bagian penting dalam penggarangan proses laundry. Agar proses menyetrika lebih efisien pisahkan bahan-bahan sejenisnya dari yang tipis sampai yang bahan yang tebal seperti jeans. Tujuannya agar suhu stetrika tidak sering diubah dan pemanasan setrika berurutan dari dingin, hangat, sampai panas (Rezeki, 2020).

Seterusnya proses setrika dilanjutkan dengan proses penyemprotan pewangi dan pengepakan. Proses pengepakan diawali dahulu dengan pakaian tebal pada bagian bawah lalu semakin keatas pakaian lebih tipis. Setelah pakaian tertata rapi baru dilanjutkan dengan proses packing kedalam plastik. Setelah proses kesiapan, dilanjutkan pemberian nama, nomor nota dan jumlah pakaian dengan spidol permanent pada permukaan atas pada plastic. Letakkan cucian kiloan yang sudah di packing dan di tempel nota pada rak, urutkan penempatan dari nomor kecil ke nomor besar (Rezeki, 2020).

Laundry on premises (instansi pribadi) umumnya beroperasi dihotel tersendiri, industri, rumah merawak/menyusu, rumah sakit pribadi dan industri pabrik. Jasa yang disediakan digunakan untuk keperluan internal. Dan terakahir laundry koin, umumnya dijalankan oleh perorangan atau instansi kecil seperti apartemen, rumah susun disebut sebagai laundry kelembagaan. Yang beroperasi diarea institusi sistem, tahanan rumah dan institusi kesehatan mental. Produk yang dilayani mirip dengan laundry komersil dan rumah sakit. Kelima, laundry on premises (instansi pribadi) 
umumnya beroperasi dihotel tersendiri, industri, rumah merawak/menyusu, rumah sakit pribadi dan industri pabrik. Jasa yang disediakan digunakan untuk keperluan internal. Dan terakahir laundry koin, umumnya dijalankan oleh perorangan atau instansi kecil seperti apartemen, rumah susun disebut sebagai laundry kelembagaan (Rezeki, 2020).

\section{Profil Usaha Laundry Syariah Arransha}

Arransha Laundry beralamat di Jln. A. Yani Desa Gampong Paya Bujok Seuleumak Kecamatan Langsa Baro Kota Langsa. Arransha Laundry didirikan pada tanggal 28 Oktober 2018 oleh pemilik Ibu Nora Veri dengan modal awal sebesar Rp. 35.000.000,- (tiga puluh lima juta rupiah) (Veri, 2020b).

Usaha laundry Arransha ini juga memiliki tujuan untuk membuka lapangan pekerjaan bagi warga sekitar dengan memberdayakan para ibu rumah tangga yang ingin memiliki penghasilan tambahan. Target pasar laundry ini menyasar para pekerja seperti PNS, Pegawai Kantoran, Mahasiswa, dan orang-orang yang ingin praktis dalam hal pencucian pakaian. Promosi yang digunakan laundry ini dalam mengenalkan serta memasarkan produknya hanya dengan memasang spanduk didepan usaha laundrynya (Veri, 2020b).

\section{Praktik Jasa Laundry Syari'ah Arransha Kota Langsa}

Pada umumnya Jasa yang diterapkan dipelbagai unit usaha sebagai berikut: Pertama, memilah pakaian sebelum mencuci berdasarkan tingkat kekotorannya. Kedua, tidak merendamkan kaos, celana, baju, dan lain-lain yang disablon terlalu lama lebih dari satu jam didalam larutan deterjen agar tidak rusak. Ketiga, pakaian dicuci dengan deterjen yang dapat membunuh kuman agar kotoran-kotoran yang menempel dipakaian tersebut dapat bersih. Keempat, pada bilasan terakhir biasanya menggunakan cairan pelembut dan pewangi pakaian untuk hasil pencucian yang terbaik (Veri, 2020b).

Praktik Arransha laundry syari'ah pasca peneliti mewancarai pemilik dan stafnya sebagai berikut: a. Pakaian dihimpun dari konsumen; b.Pakaian akan dipilah; c. Pakaian dicuci dengan menggunakan deterjen; d. Pakaian akan dibilas; e. Pakaian akan disucikan (thaharah); f. Pakaian akan dikeringkan; g. Pakaian akan disetrtika; dan g. Pakaian akan dipaketkan (Irma, 2021).

Analisa peneliti dalam hal thaharah, seharusnya konsep thaharah bukan hanya satu sesi pada saat pensucian baju akan tetapi thaharah harus dimaknai sebagai holistik dan berkelanjutan dalam pengerjaannya. Praktik laundry Arransha sebaiknya menggunakan konsep thaharah secara keseluruhan walaupun praktik yang sekarang tidak demikian. Seharusnya pengerjaan thaharah sudah dimulai dari awal penerimaan kain atau objek yang akan di laundry, karena konsepsi thaharah menjadi keseluruhan setiap rangkaian praktik laundry yang dikerjakan.

\section{Tinjauan Fiqh Muamalah Praktik Jasa Laundry Syari'ah Arransha Kota Langsa}


Secara konsepsional sudah dijelaskan bahwa fiqh muamalah sebagai grand theory yang dijadikan acuan untuk batu ujian terhadap praktik jasa laundry syari'ah Arransha Kota Langsa. Sejauhmana tinjauan fiqh mualamah terhadap beberapa praktik yang dilakukan oleh laundry syari'ah Arransha tersebut. Dalam Alquran surat Al-Baqarah ayat 282 dijelaskan bagaimana dasar fiqh muamalah sehingga dapat dijadikan patokan dibeberapa frasa-frasa yang menjadi masalah utama penelitian ini (Muaidi, 2016).

Asas-asas QS Al Baqarah ayat 282 menjelaskan bahwa setiap usaha yang dijalankan harus ada mekanisme pencatatan yang baik sehingga konsumen juga tidak dirugikan dalam perjalanannya (Muaidi, 2016). Berdasarkan dari hasil analisis diatas dalam praktik jasa laundry syari'ah Arransha Kota Langsa sebagai berikut:

Pertama, bahwa dalam keseharian bisnis jasa laundry syariah Arransha para pihak baik laundry Arransha Kota Langsa dengan pelanggan langsung terlibat dengan akad. Dalam hal ini yang dimaksud para pihak yakni pemilik dan karyawan laundry syari'ah Arransha Kota Langsa dan konsumen menjadi pelaku keduanya sudah aqil dan baligh, dan sudah terdiri dari dua orang atau lebih. Dalam rangkaian peneliti, unsur-unsur ini sudah ada dalam perjalanan laundry syari'ah Arransha. Kedua, bahwa sesuatu yang hendak diakadkan sebagai objek akad. Disini objek akad yang dimaksud yakni berupa jasa, yang mana jasa adalah suatu barang yang tidak dilarang oleh syara' (boleh atau mubah). Barang tersebut yakni berupa baju, selimut, boneka dan lain-lain. Ketiga, sighat akad yakni kalimat perjanjian (akad) yang lazimnya dilaksanakan melalui pernyataan ijab dan pernyataan qabul. Disini kedua belah pihak sudah melakukan ijab dan qabul pada awal transaksi laundry syari'ah Arransha tersebut dan saling rela. Dalam praktiknya di jasa syari'ah laundry Arransha sudah disebutkan ketentuan-ketentuan yang terdapat di nota kwintasi sebagai berikut: (Muaidi, 2016).

1. Barang yang tidak diambil dalam waktu 10 hari, diluar tanggungjawab Arransha Laundry;

2. Periksa kembali barang anda sebelum meninggalkan Arransha Laundry;

3. Ganti rugi $50 \%$ dari harga barang;

4. Terima kasih telah membaca ketentuan ini.

Frasa "barang yang tidak diambil dalam waktu 10 hari, diluar tanggung jawab Arransha Laundry" secara fiqh muamalah dapat ditelaah sepihak dari laundry syari'ah Arransha seharusnya frasa mengandung prinsip saling radha'ah kedua belah pihak. Menurut data yang peneliti temukan dari salah satu konsumen teks bon yang diatas sama sekali hanya menguntungkan sepihak (Muaidi, 2016).

Salah satu wawancara bersama konsumen atau pelanggaan laundry syari'ah Arransha Kota Langsa dengan Ibu Khairani tidak begitu setuju dengan barang yang tidak diambil dalam waktu 10 hari diluar tanggungjawab Laundry Arransha sebagai berikut: 
Pernah saya mengambil barang di atas 10 hari terkesan tidak dilayani seharusnya sikap seperti ini diminamilisir oleh staf-staf pegawai laundry Arransha Label syari'ah bukan hanya sebatas ada thaharah namun sikap lemah lembut ke pelanggan menjadi tolak ukur ke depannya (Muaidi, 2016).

Ketentuan radha'ah ini juga sudah diatur dalam Alquran Al-Baqarah ayat 233 sebagai berikut:

Para ibu hendaklah menyusukan anak-anaknya selama dua tahun penuh, yaitu bagi yang ingin menyempurnakan penyusuan. dan kewajiban ayah memberi makan dan Pakaian kepada para ibu dengan cara ma'ruf. seseorang tidak dibebani melainkan menurut kadar kesanggupannya. janganlah seorang ibu menderita kesengsaraan Karena anaknya dan seorang ayah Karena anaknya, dan warispun berkewajiban demikian. apabila keduanya ingin menyapih (sebelum dua tahun) dengan kerelaan keduanya dan permusyawaratan, Maka tidak ada dosa atas keduanya. dan jika kamu ingin anakmu disusukan oleh orang lain, Maka tidak ada dosa bagimu apabila kamu memberikan pembayaran menurut yang patut. bertakwalah kamu kepada Allah dan Ketahuilah bahwa Allah Maha melihat apa yang kamu kerjakan.

Albaqarah ayat 233 di atas menjelaskan secara prinsipil radha'ah terhadap perkembangan ekonomi Islam, termasuk mengenai pengelolaan laundry syari'ah Arransha. Artinya penggunaan frasa diatas tidak ada tolak ukur yang jelas, seharusnya ada pra simulasi terhadap frasa teks tersebut (Muaidi, 2016).

Praktik operasional laundry syari'ah Arransha secara tekstual lainnya adalah mengenai "ganti rugi 50\% dari harga barang" lebih dekat kepada mengganti (rugi) atau membayar kompensasi dalam bahasa Arab disebut sebagai al-ta'widh. Secara istilah adalah menutup kerugian yang terjadi akibat pelanggaran atau kekeliruan. Kemudian kerugian yang menimpa seseorang, baik menyangkut dirinya atau harta kekayaannya, sehingga menimbulkan berkurangan kualitas, kuantitas, ataupun manfaatnya disebut sebagai kerugian ekonomis. Secara konsep fiqh mualamah 50\% dari harga barang sudah mengandung kaidah saddz az-zari'ah yang pada prinsipnya mencegah, melarang, menutup jalan atau wasilah suatu pekerjaan yang awalnya dibolehkan karena dapat menimbulkan sesuatu yang menyebabkan terjadinya kerusakan atau sesuatu yang dilarang (Muaidi, 2016).

Sementara pada praktiknya, pihak jasa Laundry Arransha selalu menolak bertanggung jawab jika ada laporan ataupun pengaduan dari pelanggan maupun konsumen yang meminta tanggung jawab atas kelalaian ataupun kesalahan yang dilakukan oleh pihak jasa Laundry Syariah Arransha.

Kemudian, tinjauan fiqh muamalah praktik operasional jasa laundry Arransha secara kontekstual sebagai berikut:

Pertama, bahwa menghimpun pakaian dengan pelayanan yang berkualitas, memberikan pelayanan yang baik, dan bukan yang buruk 
diartikan sebagai tahapan penerimaan pakaian itu secara prinsip hal tersebut adalah fiqh muamalah. Yang harus dihadirkan dalam tahapan penerimaan pakaian itu bukan saja hanya berkualitas namun harus mengerti, memahami, dan merasakan apa maunya konsumen. Dengan demikian maka penyampaian akan sampai pada heart share dan memperkokoh posisi di dalam mind share konsumen. Artinya laundry syari'ah Arransha harus ada indikator kualitas pelayanan dalam Islam disebut dengan standarisasi syari'ah (Muaidi, 2016).

Alquran menginformasikan bahwa kualitas melayani tamu atau konsumen perspektif fiqh muamalah al-Baqarah ayat 267 sebagai berikut:

Hai orang-orang yang beriman, nafkahkanlah (di jalan Allah) sebagian dari hasil usahamu yang baik-baik dan sebagian dari apa yang kami keluarkan dari bumi untuk kamu. dan janganlah kamu memilih yang buruk-buruk lalu kamu menafkahkan daripadanya, padahal kamu sendiri tidak mau mengambilnya melainkan dengan memincingkan mata terhadapnya. dan Ketahuilah, bahwa Allah Maha Kaya lagi Maha Terpuji.

Kedua, tahapan pencucian ini sekilas sudah dijelaskan namun yang perlu disikapi adalah pra pencucian, pencucian dan pasca-pencucian. Melakukan pemilahan pakaian yang kotor atau tidak berdasarkan pakaian dewasa dan anak-anak serta perendaman sebelum mulai mencuci. Hal ini penting untuk memberikan waktu persiapan sebelum pencucian utama, dengan alasan memberikan waktu untuk pakaian ditambahkan dengan deterjen dan pemutih pakaian (Muaidi, 2016). Air yang digunakan di laundry syari'ah Arransha dari air sumur bor, dengan kualitas yang cukup bagus hal ini dijelaskan dalam Alquran al-Mursalat ayat 27 sebagai berikut:

Dan kami jadikan padanya gunung-gunung yang tinggi, dan kami beri minum kamu dengan air tawar?

Menurut Peraturan Menteri Kesehaan Nomor 32 Tahun 2017 tentang Standar Baku Mutu Kesehatan Lingkungan dan Persyaratan Kesehatan Air Untuk Keperluan Higienis Sanitasi, Kolam Renang, Solus Per Aqua, dan Pemandian Umum penelitian bahwa kedalaman air sumur sesuai dengan standar baku mutu kesehatan lingkungan bisa dikonsumsi untuk kebutuhan rumah tangga (Muaidi, 2016).

Ketiga, bisa juga menggunakan dengan alat pengering, pakaian yang sudah kita keluarkan dari mesin cuci kita gantung dengan hanger dalam ruangan tertutup, lalu nyalakan alat pengering dan stel timer pada tombol 2 jam. Buatlah ruangan khusus yang tertutup rapat, dengan sedikit ventilasi untuk penguapan. Kemudian tahapan pengeringan ini menggunakan pakaian yang sudah dikeluarkan dari mesin cuci bisa langsung dimasukkan kedalam pengeringan, lalu kita tunggu sampai selesai. Kemudian pakaian yang dikeringkan menggunakan mesin pengering biasanya akan lebih sulit disterika, apalagi kain yang berbahan nilon mudah rusak, maka tahap pencucian gunakanlah softener. Biasanya untuk pakaian 20-30 kg dapat kering kira-kira 2 jam. Pakaian yang tebal seperti jeans, jaket, dan lain-lain akan sedikit memakan waktu yang agak lama (Wawan, 2021). 
Kemudian pakaian yang akan dijemur dibalik terlebih dahulu (bagian dalam diluar) agar warna pakaian tidak kusam apabila menggunakan pengeringan dengan sinar matahari, Sebaiknya pengeringan dengan bantuan sinar matahari sebaiknya tidak terlalu kering kerontak karena mengakibatkan bau matahari. Dalam Alquran Al-Hajj ayat 70 sebagai berikut:

Apakah kamu tidak mengetahui bahwa Sesungguhnya Allah mengetahui apa saja yang ada di langit dan di bumi?; bahwasanya yang demikian itu terdapat dalam sebuah Kitab (Lauh mahfuzh). Sesungguhnya yang demikian itu amat mudah bagi Allah.

Keempat, tahapan setrika pakaian yang telah kering dapat langsung dimasukkan kedalam keranjangan pakaian. Pisahkan pakaian, mana yang bias langsung disetrika biasa (dry iron) dan yang perlu disetrika menggunakan setrika uap. prinsipnya menyetrika pakaian baju memang identik dengan ketelitian dan kebutuhan waktu yang tidak sebentar dalam mengerjakannya. Menurut wawancara peneliti pakaian yang disetrika tidak dipisahkan seharusnya penyetrikaan baju harus dipisahkan berdasarkan jenis bahan pakaian, misalnya bahan kaos. Menyetrika baju kaos ini terbilang mudah biasanya hanya dari bagian belakang dan kemudian ke bagian depan. Jika kaos memiliki cetakan sablon sebagai motifnya sebaiknya hindari menyetrikanya. Hal ini dikarenakan panas setrika dapat merusak cetakan sablon (Erlinda, 2021).

Kelima, bagian packing sudah layak dan benar yang dilakukan oleh laundry Arransha yang menjadi catatan peneliti untuk jas hendaknya tidak dilipat akan tetapi dipacking dengan gantungan jas jadi baju jas tidak mudah kusut. Namun sebaiknya tidak menggunakan plastik karena bungkusan plastik akan menjadi sumber masalah dikemudian hari menumpuknya sampah. Sisi lain prinsip laundry syari'ah Arransha tidak hanya sebagai motto namun praktik juga harus memahami pasca dari packing dan pembuangan limbah air harus dikelola dengan baik (Satrika, 2021).

Dapat dipahami bahwa praktik jasa laundry syari'ah Arransha secara fiqh muamalah khusus kaidah ushul fiqh la dharara wa la dhirar sebagai jalan agar praktik lebih menekankan mafsadah dan mendekati manfaat atas nilai usaha laundry syariah Arransha yang dijalankan. Paling penting dalam praktik tersebut tidak melangkahi prosedural yang sudah ditentukan. Karena prinsip la dharara wa la dhirar tujuan yang ditentukan itu wajib menghindari mafsadah dan mendekati manfa'ah. Artinya, jika jasa yang dijual dalam bingkai syariat Islam yang artinya bersih, suci, dan ekonomis maka prosesnya juga tidak bisa menyimpangi. Kemudian niatnya bukan hanya bisnis semata dengan meraup laba yang sebesar-besarnya akan tetapi menerapkan nilai-nilai islam yang ingin ditawarkan sebagai branding syiar Islam. Terakhir, akibat suatu perbuatan menghasilkan kemaslahatan seperti yang diajarkan syari'ah maka wasilah hukumnya boleh dikerjakan dan sebaliknya jika akibat perbuatan adalah kerusakan walaupun tujuan demi kebaikan, maka hukumnya tidak boleh (Nasution, 1997). 
Kemudian dari uraian-uraian di atas, peneliti menggambarkan dalam bentuk bagan praktik jasa laundry syari'ah Arransha Kota Langsa sebagai berikut:

Gambar1. Bagan hasil penelitian pada laundry syari'ah Arransha Kota Langsa:

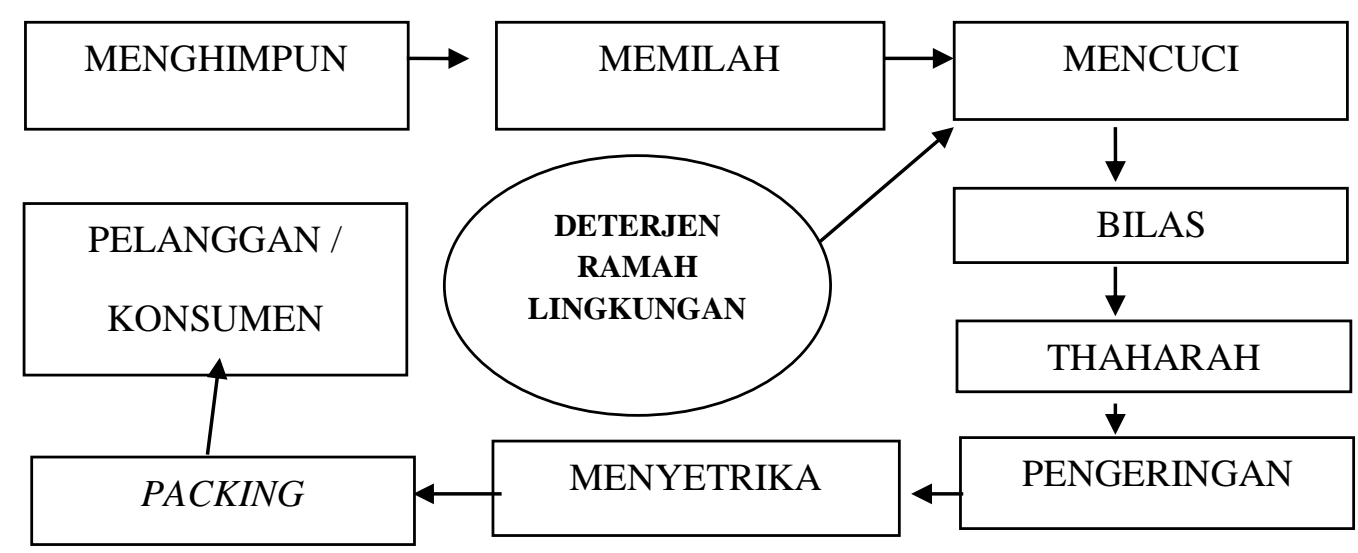

Peneliti dalam hal ini menganalis dari bon yang digunakan sebagai akad melalui kesepakatan bersama antara laundry syariah Arransha dengan para konsumen, uraian di bawah aturan hukum mengenai terminasi akad melalui aqad al-iqalah sebagai berikut: (Sri Imaniyati, 2011).

1) Pada dasarnya terjadinya akad dengan ijab dan kabul para pihak, maka yang berlakukan iqalah adalah para pihak yang bersangkutan. Artinya, pihak laundry Arrhansa dengan pelanggan harus jelas terlebih dahulu sehingga pakaian yang hendak diserahkan benar-benar sesuai dengan bon yang tertera sehingga tidak ada unsur ketidakpastian. Hak ini juga dalam konteks waris sudah dikembangkan, ahli waris, wail, dengan kuasa dari pihak yang berhak, serta fudhuli (pelaku tanpa kewenangan) dengan ketentuan akibat hukumnya yang baru berlaku setelah mendapatkan ratifikasi dari yang berhak.

2) Hapus akad yang telah dibuat akibat hukumnya dan para pihak dikembalikan kepada status semula seperti sebelum terjadi akad. Hal ini tentu ketika dilakukan al-iqalah maka syarat objeknya masih ada. Misalnya ketika di bon laundry ada pengembalian barang ketika terjadi kerusakan maka itu harus digantikan selama barang tidak ada atau ketika rusak dalam penyetrikaan maka pelanggan bisa saja komplain ke pihak laundry syariah Arransha yang bersangkutan.

3) Ketika kecurangan muncul maka semua yang berkaitan akad juga bubar seperti akad penanggungan yang mengikuti akad pokok.

4) Pihak ketiga, iqalah merupakan suatu akad baru dalam rangka memberikan perlindungan terhadap pihak ketiga tersebut.

5) akad iqalah berlaku khiyar syarat, misalnya penjual menemukan cacat yang terjadi ditangan pembeli pada barang yang dikembalikan pembeli yang tidak diketahui oleh penjual saat melakukan iqalah, maka ia berhak 
mengembalikan barang tersebut kepada pembeli (tidak jadi melakukan iqalah).

\section{Kesimpulan}

Hasil analisis yang telah diuraikan pada bab-bab sebelumnya, maka dapat disimpulkan antara lain:

1. Bahwa praktik jasa laundry syari'ah Arransha Kota Langsa sudah sesuai dengan prosedur laundry pada umumnya, yaitu sudah sesuai dengan standar S.O.P. seperti memilah dan milih pakaian yang akan dicuci antara pakaian orang dewasa dan anak-anak, pakaian dicuci dengan menggunakan deterjen, pakaian dibilas, pakaian akan disucikan, pakaian dikeringkan, pakaian disetrika, pakaian dipaketkan dan pakaian diletakkan dalam rak kemudian pakaian siap diambil kembali oleh konsumen.

2. Penekannya di praktik jasa laundry syariah Arransha ini belum menggunakan konsepsi thaharah secara keseluruhan. Kesucian sebagian dari iman. Syarat sah tidaknya sholat adalah suci bersih badan, pakaian dan tempat ibadah. Dengan mendirikan sholat berarti kita telah memelihara agama yang merupakan tujuan maslahah (maqasid) syariah. Prinsip menyiapkan diri dengan kondisi terbaik saat menghadap Allah SWT tidak hanya bersih akan tetapi suci. Selain itu juga pakaian yang digunakan dalam keadaan suci dan bersih dapat menjaga kesehatan karena hal ini juga merupakan bagian dari tujuan hukum Islam, terdapat dalam teori maqashid syariah yaitu memelihara jiwa (kesehatan). Bahwa tinjauan fiqh muamalah terhadap praktik laundry Arransha, belum memenuhi unsur fiqh muamalah seperti adanya pelanggaran akad yang tertera dalam nota bon, yaitu ganti rugi barang sebesar 50\%, namun kenyataannya tidak demikian. Pihak laundry syariah Arransha tidak menunaikan sebagaimana yang telah diakadkan. Seharusnya pihak laundry syariah Arransha memberikan ganti rugi (Dhaman) barang konsumen yang rusak maupun hilang sebagaimana yang telah disepakati dalam akad. Disini konsumen merasa kecewa dan dirugikan oleh laundry syari'ah Arransha. setiap akad (transaksi) yang tidak dilandasi kerelaan dari kedua belah pihak yang berakad maka akad (transaksi) yang dilakukan menjadi batal.

Kemudian ada ketentuan dari pihak laundry syariah Arransha yang tidak dijelaskan kepada konsumen, yaitu paket hanya berlaku sekali dalam sebulan dari tanggal 1 s.d. 31, artinya jika konsumen laundry menggunakan layanan paket tidak habis digunakan dalam tempo 1 bulan, maka sisa paket yang masih ada akan dihapuskan. Disini terjadinya unsur ketidakjelasan (gharar). Muamalah dilakukan dengan rasa suka sama suka (rela) atas dasar pertimbangan mendatangkan kemaslahatan (manfaat) dan memelihara nilai keadilan serta menghindari mudaharat (unsur-unsur kedzaliman). setiap muamalah yang menimbulkan mudharat adalah batal. 


\section{Daftar Pustaka}

Abdullah, S. S. dan R. (2011). Fikih Muamalah. Bogor: Ghalia Indonesia.

Agustinar. (2021). Perlakuan Akuntansi Terhadap Pembiayaan Murabahah. $A l$ Mashaadir: Jurnal Imu Syariah, Vol.2, No., 27-48.

Ahmad, A. dan B. (2010). Metodologi Penelitian Kualitatif. Bandung: Pustaka Setia.

Al-Mas'adi, G. (2002). Figh Muamalah Konstekstual. Jakarta: Raja Grafindo Persada.

Arikunto, S. (2013). Prosedur Penelitian Suatu Pendekatan Praktis, Edisis Revisi 15,. Jakarta: Rineka Cipta.

Asutay, M. (2012). Conceptualising and Locating the Social Failure of Islamic Finance: Aspirations of Islamic Moral Economy vs the Realities of Islamic Finance. アジア・アフリカ地域研究 = Asian and African area studies, 11(2), 93113.

Az-Zuhaili, W. (1984). Al-Figh al-Islami wa Adilatuhu Jidil IV,. Beirut: Dar-al-Fikr.

Azmi, A. (2014). "Economic Ideas of Ibn 'Abidin: A Legal Analysis", Volume 53 Nomor 1, 2014, h. 85. Islamic Research Institute Internastional Islamic University, Vol.53.

Dewi, G. (2005). Hukum Perikatan Islam Indonesia. Jakarta: Preneda Media Group.

Djuwaini, D. (2008). Pengantar Fiqh Muamalah,. Yogyakarta: Pustaka Pelajar.

Dkk, I. (2006). Metodologi Penelitian Bisnis. Yogyakarta: BPFE Yogyakarta.

Ekasari Lieharyani Lokmansyah, \& Rika Harini. (2019). Kajian Usaha Laundry Di Dusun Pogung Kidul Desa Sinduadi Kecamatan Mlati, (2).

Eprianti, N., \& Adhita, O. (2017). Pengaruh Pendapatan Ijarah Terhadap Profitabilitas. Amwaluna: Jurnal Ekonomi dan Keuangan Syariah, 1(1), 19-33. https: / /doi.org/ 10.29313/amwaluna.v1i1.1994

Erlinda. (2021). Wawancara bersama Erlinda karyawan Laundry Arransha bidang setrika pada tanggal 1 Februari 2021 di Laundry syariah Arransha Kota Langsa. Langsa.

HAK, N., \& Yuswalina, Y. (2019). KONSEP FIDUSCIAIRE EIGENDOMS OVERDRACHT DALAM KAJIAN FIQH MUAMALAH. Nurani: Jurnal Kajian Syari'ah dan Masyarakat, 19(1), 77-90. https://doi.org/10.19109/nurani.v19i1.2711

Handoko, H. (2013). Sukses Wira Usaha Laundry di Rumah. Jakarta: Jakarta: Gramedia.

Harun. (2017). Fiqh Muamalah. Surakarta: Muhammadiyah University Press.

Huda, Q. (2011). Fiqh Muamalah. Yogyakarta: Teras.

Irma. (2021). Wawancara bersama Ibu Irma selaku pelanggan cuci komplit Laundry Syari'ah Arransha Kota Langsa, pada tanggal 25 Januari 2021. Langsa.

Karim, A. A. (2005). Bank Islam, Analisis Fiqh dan Keuangan. Jakarta: Raja Grafindo Persada. 
Ma'luf, L. (1986). Al-Munjid fi Al-Lughah wa Al-A'lam. Beirut: Dar al-Masyriq.

Masruroh, A. T. (2021). TINJAUAN FIQH MUAMALAH TERHADAP PENERAPAN AKAD DALAM PEGADAIAN SYARIAH. Minhaj: Jurnal Imu Syariah, 2(1), 1-16. https://doi.org/10.52431/minhaj.v2i1.308

Muaidi. (2016). Saddu Al-Dzari'ah Dalam Hukum Islam. Tafaqquh: Hukum Ekonomi Syariah Dan Ahwal Syahsiyah, 1(2), 34-42.

Nasution, H. (1997). Ushul Figh I. Jakarta: Logos Wacana Ilmu.

Nazir, M. . (1998). Metode Penelitian. Jakarta: Ghalia Indonesia.

Nuh, I. (2020). Wawancara bersama Ibu Nuh selaku konsumen Laundry Syari'ah Arransha pada tanggal 12 November 2020. Langsa.

Nur Khusna, F., Rio Pane, A., \& Mufida, R. (2021). Tinjauan Fiqh Muamalah Terhadap Pelaksanaan Akad Murabahah Pada Perbankan Syariah. Kunuz: Journal of Islamic Banking and Finance, 1(2), 61-73. https: / / doi.org/10.30984/kunuz.v1i2.49

Priestnall, S. L., Okumbe, N., Orengo, L., Okoth, R., Gupta, S., Gupta, N. N., ... Chatterjee, R. (2020). No 主観的健康感を中心とした在宅高齢者における 健康関連 指標に関する共分散構造分析Title. Endocrine, 9(May), 6.

Pristi, D. (2020). Wawancara pra penelitian bersama Dita Pristi selaku staf pegawai Laundry Arransha bidang kasir pada tanggal 28 Oktober 2020. Langsa.

Rezeki, S. S. (2020). ICoMS2020, 1(1), 28-35.

Salahudiin, M. (2007). Asas-Asas Ekonomi Islam. Jakarta: Raja Grafindo Persada.

Satrika, R. (2021). Wawancara bersama karyawan Laundry Arransha bidang packing pada tanggal 1 Februari 2021 di Laundry syari'ah Arransha Kota Langsa. Langsa.

Sayono. (2011). Metodologi Penelitian. Yogyakarta: Mitra Cendikia Press.

Shihab, M. Q. (2017). Tafisr al-Misbah: Pesan, Kesan, Keserasian Alquan, (Jakarta: Lentera Hari, 2017), h. 402-412. Jakarta: Lentera Hari.

Sri Imaniyati, N. (2011). Asas dan Jenis Akad dalam Hukum Ekonomi Syariah: Implementasinya pada Usaha Bank Syariah. Fakultas Hukum, Universitas Islam Bandung, 27(2), 151-156.

Sudiarti, S. (2018). Fiqh Muamalah Kontemporer,. Medan: FEBI UIN-SU Press.

Veri, N. (2020a). Wawancara bersama Nora Veri selaku Pemilik Laundry Arransha Laundry pada tanggal 02 Oktober 2020. Langsa.

Veri, N. (2020b). Wawancara bersama Nora Veri selaku pemilik laundry syariah Arransha di Gampong Paya Bujok Seuluemak Langsa Baro Kota Langsa pada tanggal 24 November 2020. Langsa.

Wawan. (2021). Wawancara bersama Wawan selaku karyawan bidang jemur pakaian di laundry syariah Arransha di Gampong Paya Bujok Seuluemak Langsa Baro Kota Langsa pada tanggal 14 Januari 2021. Langsa. 